\title{
Thyroid Hormone Receptor
}

National Cancer Institute

\section{Source}

National Cancer Institute. Thyroid Hormone Receptor. NCI Thesaurus. Code C17078.

A nuclear receptor that specifically binds to and is activated by thyroid hormone. 